\title{
ISSUES OF OPTIMAL USE OF KARAKULCHIK CLUSTERS IN THE DEVELOPMENT OF PASTURE LIVESTOCK
}

\author{
Yakhyaev Maksud Mavlonovich \\ Basic Doctoral Student, «Tashkent Institute of Irrigation and Agricultural Mechanization Engineers» \\ National Research University, Tashkent, Uzbekistan
}

\begin{abstract}
The purpose of the dissertation work was to develop theoretical and methodological approaches and practical recommendations for improving the organizational and economic mechanism in the region's animal husbandry. In accordance with the goal set, the following main tasks were solved: the essence, content and basic conditions for the effective functioning of the organizational and economic mechanism in animal husbandry were disclosed; the main factors influencing the efficiency of livestock production have been identified; justified priority areas for improving the organizational and economic mechanism for increasing the efficiency of production, processing and sale of livestock products; proposals were developed for the development of cooperation and integration of production and sale of livestock products. The subject of the study was a system of theoretical and practical problems of the effective functioning of the organizational and economic mechanism for the production and sale of livestock products. The object of the study was the animal husbandry of the Republic of Uzbekistan.
\end{abstract}

KEYWORDS. Livestock, cluster, development, mechanism, products

\section{INTRODUCTION}

In the course of economic reforms in agriculture, land and property relations were transformed, multi-structural production developed, the public sector was significantly reduced and private entrepreneurship occupied a dominant position.

The liquidation of the state system of production management, the rupture of existing economic ties in the agro-industrial complex, a sharp violation of the parity of prices for agricultural and industrial products created unfavorable conditions for the development of animal husbandry, led to a reduction in the production of its products and its unprofitability.

All this necessitates the development of such an organizational and economic mechanism in the sphere of production, processing and sale of livestock products, which would limit the monopoly of the processing industry and trade, stimulate the growth in the production of milk, whole milk and meat products, profitability of producers, reliable provision of the population with quality products at affordable prices. prices.

In the conditions of a market economy and its inherent competition, there is a differentiation of large, medium and small-scale forms of management in terms of the level of development and production efficiency, as well as their integration and cooperation.
The development of integrated formations in animal husbandry and the improvement of the organizational and economic mechanism of their functioning require special study.

In order to prevent the development of negative processes in animal husbandry, it is necessary to ensure the material interest of agricultural producers in increasing the production of livestock products by improving the performance of the industry as a whole, using a more efficient organizational and economic mechanism in the production and sale of its products.

The urgency of solving the problem of improving the development of the organizational and economic mechanism in animal husbandry, taking into account the specifics of national economic practice, and based on the best practices of foreign countries, predetermined the topic of the dissertation and the range of issues considered in it.

\section{METHODS, METHODOLOGIES}

However, the diversity and change in approaches to the development of the organizational and economic mechanism in animal husbandry indicate that the concept of economic processes, the nature and degree of state intervention in them have not yet been formed. The questions of improving the organizational and economic mechanism for the functioning of various forms of management on the basis of cooperation and integration require much more and detailed consideration. The development of 
the organizational and economic mechanism of large, medium and small-scale forms of management on the basis of cooperation and integration in animal husbandry did not become the object of a comprehensive analysis due to their underdevelopment and incompleteness of formation.

Many works of domestic and foreign agricultural economists are devoted to the study of the problem of the development of the organizational and economic mechanism in agriculture. Thus, the theoretical, methodological and applied issues of the organizational and economic mechanism in the industry are reflected in the works of Ashirov M.I., Khushmatov N., Babin A.A., Kuznetsov V.V., Karibaev K.K., Rubezhny, A. A., Smeyanov, A., Sadullaev U.

The theoretical, methodological and methodological basis of the study were the works of domestic and foreign scientists-economists on the development of the organizational and economic mechanism of agricultural production, scientific research and recommendations Ministry of Agriculture of the Republic of Uzbekistan, Ministry of Water Resources of the Republic of Uzbekistan, Ministry of Investment and Foreign Trade of the Republic of Uzbekistan, State committee on statistics of the Republic of Uzbekistan. The source materials were data from the state statistics service, regulatory documents of republican and regional governments on the organization of state, regional and local governments of the Republic of Uzbekistan.

\section{ANALYSIS AND RESULTS OF THE STUDY}

As a result of water supply to pastures, the number of livestock has increased, new jobs have been created, and the unemployed in remote desert areas have been provided with jobs and forced displacement has been prevented.

By the Decree of the President of the Republic of Uzbekistan No. PF-6059, the Committee for the Development of Silkworm Breeding and Astrakhan was established, and 17.4 million hectares of pastures in the country were transferred to the balance of this committee. In accordance with the requirements of the decree, the Committee has established 52 karakul clusters as of 2021, effective use of pastures for clusters, prevention of their deterioration, increase of small horned cattle using scientific and innovative approaches, establishment of cooperative relations between cluster participants. is responsible for the organization of deep processing of raw materials and production [].

However, the committee has organized its activities mainly in the central, southern and western regions of the country, where the karakul industry is well developed and has the potential to accelerate the development of the wool industry. In particular, karakul clusters have been established in the Republic of Karakalpakstan, Bukhara, Jizzakh, Kashkadarya, Navoi, Samarkand, Surkhandarya and Khorezm regions. There are no clusters on existing pastures in Tashkent, Syrdarya, Andijan, Fergana and Namangan regions. Pastures in these areas are used by farms, dehkan farms and agricultural enterprises (Table 1).

Table 1. Pasture areas allocated by karakul clusters in the Republic and pastures leased by clusters to economic entities for secondary lease (2021)

\begin{tabular}{|l|c|c|c|}
\hline \multicolumn{1}{|c|}{ Name of regions } & $\begin{array}{c}\text { Number of } \\
\text { astrakhan } \\
\text { clusters }\end{array}$ & $\begin{array}{c}\text { Pasture area } \\
\text { allocated to clusters, } \\
\text { thousand hectares }\end{array}$ & $\begin{array}{c}\text { Pasture land allocated to } \\
\text { business entities by clusters }\end{array}$ \\
\hline $\begin{array}{l}\text { Republic of } \\
\text { Karakalpakstan }\end{array}$ & 11 & 4586 & 759 \\
\hline Bukhara & 8 & 2355 & 2012 \\
\hline Jizzakh & 3 & 522 & 522 \\
\hline Kashkadarya & 9 & 1105 & 992,2 \\
\hline Navoi & 13 & 3391 & 2903 \\
\hline Samarkand & 4 & 592 & 498 \\
\hline Surkhandarya & 3 & 632 & 544 \\
\hline Khorezm & 1 & 40 & 13 \\
\hline total & $\mathbf{5 2}$ & $\mathbf{1 3 2 2 3}$ & $\mathbf{8 2 4 3 , 2}$ \\
\hline
\end{tabular}

There are 11 karakul clusters in the Republic of Karakalpakstan, 8 in Bukhara region, 3 in Jizzakh region, 9 in Kashkadarya region, 13 in Navoi region, 4 in Samarkand region, 3 in Surkhandarya region and 1 in Khorezm region.

A total of 13.2 million hectares of pastures were allocated to these clusters on a lease basis for 49 years, and 8.2 million hectares $(62 \%)$ were allocated by clusters to livestock farms on a secondary lease basis. An average of 255,000 hectares of pastures are allocated to one astrakhan cluster, the largest pastures are 653,000 hectares (in Kyzyltepa district of Navoi region) and at least 18,000 hectares (in Forish district of Jizzakh region).

There are a total of 2.9 million heads of small cattle in the country, as well as members of their 
cooperatives, which have an average of 4.56 hectares of pasture (Table 2).

Table 2. The number of small horned cattle in the astrakhan clusters in the country and the corresponding pasture area (2021)

\begin{tabular}{|l|c|c|c|}
\hline Name of regions & $\begin{array}{c}\text { Pasture area allocated to } \\
\text { clusters, thousand } \\
\text { hectares }\end{array}$ & $\begin{array}{c}\text { Total small horned } \\
\text { cattle available, } \\
\text { head }\end{array}$ & $\begin{array}{c}\text { The area corresponding to } \\
\text { an average head of small } \\
\text { horned cattle, ha }\end{array}$ \\
\hline $\begin{array}{l}\text { Republic of } \\
\text { Karakalpakstan }\end{array}$ & 4586 & 64323 & 71,30 \\
\hline Bukhara & 2355 & 373684 & 6,30 \\
\hline Jizzakh & 522 & 257083 & 2,03 \\
\hline Kashkadarya & 1105 & 492216 & 2,24 \\
\hline Navoi & 3391 & 965874 & 3,51 \\
\hline Samarkand & 592 & 382313 & 1,55 \\
\hline Surkhandarya & 632 & 329166 & 1,92 \\
\hline Khorezm & 40 & 36541 & 1,09 \\
\hline total & $\mathbf{1 3 2 2 3}$ & $\mathbf{2 9 0 1 2 0 0}$ & $\mathbf{4 , 5 6}$ \\
\hline
\end{tabular}

In particular, the Republic of Karakalpakstan has 64,000 heads of small cattle, an average of 71.3 hectares, Bukhara region has 373.7 thousand heads of small cattle, an average of 6.3 hectares, Jizzakh region has an average of 257,000 heads of small cattle. In Kashkadarya region there are 492 thousand heads of small cattle, on average 2.2 hectares, in Navoi region there are 965.8 thousand heads of small cattle, on average 3.5 hectares, in Samarkand region there are 382 thousand heads of small cattle. on average 1.5 hectares, in Surkhandarya region there are 329.1 thousand heads of small cattle, on average 1.9 hectares, and in Khorezm region there are 36.5 thousand heads of small cattle, on average 1.09 hectares.

\section{CONCLUSIONS}

The provisions of the organizational and economic mechanism of the activity of cluster-type agro-industrial formations are based on new principles and conditions of functioning. When developing a program and strategy for the economic activities of the cluster, the priorities should be the complexity and phased nature of the activities, marketing orientation, adherence to the principles of creating and functioning of the united structure. The main principles and conditions of the organizational and economic mechanism for the creation and operation of the cluster should be: voluntary entry of participants and exit from it; compliance by all participants with legislative and other legal acts regulating the activities of economic entities, which is the most important condition for the sustainability of agro-industrial formation, the development of production and its efficiency; equal social and economic conditions for all participants. The organizational and economic mechanism should maximally limit the desire of some economic entities of a closed production cycle to a monopoly position in the agricultural market; integrity, complexity and optimal size of production concentration. Depending on the production direction, the composition of the participants, the formation can be an organizational cluster in a certain territory with a complete production cycle; support and assistance on the part of the administrative authorities of the process of formation and functioning of associations. Agricultural clusters can be created in different ways, depending on the mechanism of property reform and regulation of relations within the association, the legal status of the participants in the formation.

\section{BIBLIOGRAPHY}

1. https://www.lex.uz/docs/4980311

2. Khushmatov N., Abdullaeva S. Some problems of ensuring the competitive sustainability of livestock farms. - Collection of abstracts of the conference /. Altai State Agrarian University. -2014. (February 13) -410-412 p. (www.asau.ru).

3. Khushmatov N., Abdullaeva S. The development of animal husbandry is the basis for providing the country with food. Collection of abstracts of the international conference. PNIIAZ. -Astrakhan(Russia): - 2015. -89-91 p.

4. Sadullaev U., Sadullaev S. Solutions to the problems of livestock development in the private sector PNIIAZ. -Astrakhan - (Russia): - 2015. -94 p.Umarov, S., Durmanov, A., Li, M., Khushvaktova, K., Yakubova, K., Shanasirova, N., 2021. Features of the Application of Game Theory in the Tasks Organizational and Economic Mechanisms Greenhouse Economy. Turkish Journal of Computer and Mathematics Education, Volume 12(11), pp. 3544-3550

5. Tursunov, I., Yangiboyev, B., Babadjanov A., Tabaev, A., Durmanov, A., 2020. Application of Mathematical Theory Games When Decision on the Creation Small Business in the Agricultural Industry Republic of Uzbekistan. Solid State Technology, Volume 63(4), pp. 325-333

6. Allayarova, S., Kilichevab, F., Rakhimovac, K., Mamasadikovd, A., Khamrayevae, S., Durmanov, A. 2021. Game Theory and Its Optimum 
Application for Solving Economic Problems. Turkish Journal of Computer and Mathematics Education, Volume 12(11), pp. 34323441

7. Belousova, M., Danilina, O., 2021. GameTheoretic Model of the Species and Varietal Composition of Fruit Plantations. International Journal of Technology. Volume 12(7), pp. 14981507

8. Durmanov, A., Kalinin, N., Drobyazko, S., Yanishevska, K., Shapovalova, I. (2019). Strategic support of innovative activity of modern enterprises. 34th IBIMA Conference: 13-14 November 2019, Spain

9. Atakhanova N., Almuradova D., Khakimov G., Usmonova S., \& Durmanov A. (2020). Values of a mathematical model for predicting the survival of patients with triple negative breast cancer depending on androgen receptors. International Journal of Pharmaceutical Research, 12(3), 695704. https://doi.org/10.31838/ijpr/2020.12.03.104

10. Durmanov, A., Kalinin N., Stoyka, A., Yanishevska, K., \& Shapovalova, I. (2020). Features of application of innovative development strategies in international enterprise. International Journal of Entrepreneurship Issues, 1(24), 1-9.

11. Aliev Y.E., Kasimov, S.S., Ruzieva, D.I., Nigmatullaeva G.N., Abdurakhmanov P.M. Durmanov A.S. (2020). Agriculture provides sustainability issues of agricultural market development. International Journal of Psychosocial Rehabilitation, $24 \quad$ (8), $\quad 7508-7529$. https://doi:10.37200/ijpr/v24i8/pr280764

12. Ubaydillayev A.N., Kholmuratova G.M., Umarov S.R., Muradov R.A., Durmanov A.S. (2020). Heat and Energy-Economic Analysis for Greenhouses of the Republic of Uzbekistan. International Journal of Advanced Science and Technology Vol. 29, No. 8, (2020), pp.3285-3298

13. Durmanov, A., Bayjanov, S., Khodjimukhamedova, S., Nurimbetov, T., Eshev, A., Shanasirova, N. (2020). Issues of accounting for organizational and economic mechanisms in greenhouse activities. Journal of Advanced Research in Dynamical and Control Systems, Vol. 12, No 07-Special Issue pp. 114-126 doi: 10.5373/jardcs/v12sp7/20202089

14. Дурманов А.Ш. Инновачионные технологии и методы обучения в профессиональные образования. “Фан, таълим ва ишлаб чиқариш интеграциясини ахборот коммуникация технологиялари асосида ривожлантириш муаммолари" Республика илмий-амалий анжуман материаллари тўплами. Қарши, 2012, $97-99 \mathrm{~cm}$.

15. Дурманов А.Ш. “Формирование инновачионной стратегии аутсорсинга". "Иқ̆тисодиётни модернизациялаш шароитида хизмат кўрсатиш сохаси самарадорлигини ошириш ва инновацион фаолиятни такомиллаштириш муаммолари" мавзусидаги республика анъанавий илмий-амалий конференция. Самарқанд-2014, 219-221 cm

16. Дурманов А.Ш. «Развитие предпринимательства и сочиального партнерства в Узбекистане». «Ижтимоий хамкорлик-иқтисодий муносабатларни эркинлаштириш омили» мавзусидаги илмийамалий конференция, Тошкент-2014, 135-138 $\mathrm{cm}$.

17. Дурманов А.Ш. «Инвестиционная политика и ее реализачия в сельскомхозяйстве Республики

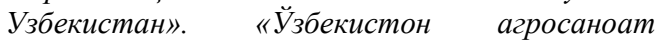
мажмуасининг рақобат бардочлигини ошириш ва экспорт салохуятини юксалтириш» мавзусидаги республика анъанавий илмийамалий конференция, Тошкент-2014, 271-274 $\mathrm{cm}$.

18. Durmanov A. Sh. Cooperation as a basis for increasing the economic efficiency of production of open ground vegetables. "Бюллетень науки и практики» 2018 г. 9

19. Durmanov A. Sh. Foreign experience the organizational-economic mechanisms of improving the activities of greenhouse farms. Economics and Finance. 2018. 7

20. Бельй В.С. История гарнизона Васьково. В книге: Арутюнова Г.И., Атаев 3. В., Бельй B.C., Братков В.В., Галаутдинова В.В., Григорьева Т.М., Дурманов А.Ш., Железная А.Б., Кудина М.В., Ла-пина С.Б., Ли М.Р., Мельников С.В., Минаков А.В., Мыльникова Е.М., Нагибина Н.П., Рудюк М.Ю., Тулабоев А.К., Холуденева А.О., Чекайкин С.В., Черновалова Г.А. $и$ др. Интеллектуальный капитал и инновационное развитие экономики, науки и образования. Монография. Пенза, 2019. С. 99-119.

21. Toxirov A., Durmanov A. The development of the education and training system, innovative management and organizational factors // Наука $и$ современное общество: взаимодействие и развитие. - Уфа: Ника, 2015. - No 1 (2). - C. 87-89.

22. Umurzakov, U., Ibragimov, A., \& Durmanov, A. (2017). Development of organizational-economic mechanism and development of scientificmethodical and theoretical bases of increase of efficiency of the industry of rice cultivation to ensure food security of the country. Bulletin of Science and Practice, (11), 103-118 doi:10.5281/zenodo.1048318

23. Umurzakov U.P., Ibragimov A.G. And Durmanov A.Sh. Factors of Stability of Development of Regional Agricultural Rice Production. International Journal of Management, IT \& Engineering. November s2017 Volume-7, Issue-11. $-4-6 p$. 